\title{
Digitalisasi UMKM sebagai Langkah Mewujudkan Pemulihan dan Resiliensi Pelaku Usaha di Masa Pandemi
}

\author{
Pierre Mauritz Sundah ${ }^{1}$, Clarissa Adeline ${ }^{2}$, Herman Purba $^{3}$ \\ ${ }^{1}$ Univerrsitas Pelita Harapan \\ ${ }^{2}$ Universitas Pelita Harapan \\ ${ }^{3}$ Universitas Pelita Harapan
}

herman.purba@uph.edu, clarissa.adeline@uph.edu,pierre.sundah@uph.edu

\begin{abstract}
Abstrak
Adanya pandemi Covid-19 menciptakan tantangan baru bagi para pelaku UMKM dari segi pemasukan, keuntungan, hingga cashflow. Data Bank Indonesia menunjukan, sebanyak 87,5\% UMKM Indonesia terdampak akibat adanya pandemi Covid-19. UMKM pada akhirnya harus membuat strategi baru sebagai amunisi untuk bertahan, salah satunya dengan melakukan digitalisasi. Namun pada praktiknya, digitalisasi tidak semudah yang dibayangkan. Kurangnya kompetensi literasi digital menjadi salah satu faktor penyebabnya. Berangkat dari hal tersebut, Program Pendidikan Jarak Jauh (PJJ) Ilmu Komunikasi Universitas Pelita Harapan (UPH) bersama dengan mahasiswa mengadakan Kegiatan Pengabdian kepada Masyarakat (PkM) melalui projek Digitalks Room dan Keluarga UMKM sebagai bentuk dukungan terhadap UMKM. Kegiatan PkM ini berfokus pada kompetensi UMKM dalam digital marketing. Dalam pelaksanaannya, kegiatan PkM ini berhasil memfasilitasi lebih dari 400 peserta dalam 2 kegiatan utama. Secara paralel, kegiatan yang pertama berbentuk webinar mengenai pemanfaatan Facebook Ads. Kegiatan kedua juga berbentuk webinar sekaligus workshop mengenai branding dalam menggunakan media sosial. Kegiatan PkM ini berlangsung secara interaktif dan mendapat antusiasme yang tinggi dari peserta. Pada akhirnya, kegiatan ini diharapkan dapat membantu pelaku UMKM dalam menerapkan digital marketing dan branding sebagai bagian dari inovasi di masa pandemi. Untuk jangka panjang, peserta pun mengharapkan adanya workshop serupa di kemudian hari secara berkala.
\end{abstract}

Kata Kunci : UMKM, branding, digital marketing, literasi digital

\section{PENDAHULUAN}

Usaha Mikro, Kecil dan Menengah (UMKM) telah menjadi motor penggerak perekonomian di Indonesia selama ini. Terdapat sekiranya 64.2 juta UMKM Indonesia yang mendukung 61.97\% Produk Domestik Bruto Negara (Kementerian Koordinator Bidang Perekonomian RI, 2021). Namun dalam dua tahun terakhir ini, perekonomian nasional mengalami penurunan yang sangat signifikan. Data dari Badan Pusat Statistik menunjukan adanya penurunan ekonomi Indonesia sebesar $2.07 \%$ dibandingkan dengan tahun sebelumnya (Badan Pusat Statistik, 2021). Salah satu faktor penurunan ini dikarenakan adanya penurunan pendapatan dari berbagai sektor, termasuk sektor UMKM. Bank Indonesia mencatat sebesar $87.5 \%$ UMKM Indonesia mengalami penurunan pendapatan.

Beberapa kendala yang ditemui pelaku UMKM diantaranya berkaitan dengan permasalahan 
finansial dan non-finansial seperti kurangnya pengetahuan tentang pemasaran. Hal ini disebabkan karena terbatasnya akses informasi yang didapat oleh pelaku UMKM. Selain itu, kurangnya pengetahuan teknologi produksi juga menjadi masalah tersendiri. Minimnya pelatihan dan akses teknologi menjadi penyebabnya (Niode, 2009).

Ditambah lagi, semenjak masuknya pandemi Covid19 di tahun 2020, pemerintah kemudian menetapkan Pemberlakuan Pembatasan Kegiatan Masyarakat (PPKM). Tentu saja hal ini menjadi permasalahan baru bagi para pelaku UMKM. Proses jual-beli yang tadinya dilakukan secara tatap muka langsung, kini harus beralih ke daring. Pelaku UMKM harus kembali mencari strategi baru untuk dapat bertahan.

Dalam menghadapi permasalah tersebut, pemerintah menyarankan UMKM untuk melakukan go digital. Namun sebelum itu, pelaku UMKM juga perlu dibekali oleh kompetensi literasi digital yang cukup untuk dapat bersaing di arus digitalisasi ini. Salah satu cara untuk meningkatkan literasi digital pelaku UMKM adalah dengan adanya pelatihan literasi media secara bertahap.

Maka dari itu, Pendidikan Jarak Jauh Ilmu Komunikasi UPH mengadakan kerja sama dengan UKM INDONESIA dalam meningkatkan kompetensi digital pelaku UMKM di Indonesia. UKM INDONESIA merupakan salah satu komunitas dan media digital pusat informasi, pengetahuan, yang membuga kesempatan bagi UMKM yang ingin naik kelas melalui Web Portal ukmindonesia.id. Organisasi ini dikelola oleh LPEM milik Universitas Indonesia, dan berperan dalam mempublikasikan ragam analisis data yang berupa kajian, advokasi kebijakan, infografis, untuk pemberdayaan UMKM Naik Kelas.

UKM INDONESIA yang dibentuk pada September 2018 kini telah memiliki anggota kurang lebih 15.000 anggota komunitas dan peserta program yang tersebar di seluruh Indonesia. Adapun portal website ukmindonesia.id ini telah diakses oleh lebih dari 50-70.000 pengunjung unik per-minggu (Hendayana, 2021).

Menurut data Kementrian Koperasi dan Usaha Kecil Menengah (Kemenpop UKM) terdapat sebanyak 3,79 juta UMKM yang sudah memanfaatkan platform daring dalam memasarkan produk mereka. Total pelaku UMKM di Indonesia ialah sebanyak 59,2 juta dan jumlah tersebut berkisar $8 \%$ dari total jumlah pelaku UMKM.

Salah satu permasalahan yang ditemui oleh UKM INDONESIA adalah kurangnya pengetahuan tentang pemasaran digital, khususnya mengenai cara membangun brand. Kotler (2021) menjelaskan branding sebagai sebuah strategi pemasaran yang terkait dengan istilah, nama, tanda, simbol, untuk mengidentifikasi sebuah barang atau jasa kelompok penjual dengan tujuan membedakan barang atau jasa tersebut dari para pesaing. Brand suatu produk ini diperlukan untuk membedakan sebuah produk dengan produk lain, serta meningkatkan promosi dan daya tarik.

Adanya kegiatan ini bertujuan untuk menjadi solusi atas permasalahan yang ditemui dan dapat membantu pelaku UMKM untuk dapat memahami proses digitalisasi pada bidang manajerial (peningkatan produktivitas, pemasaran dan pengembangan sumber daya manusia).

Kegiatan ini dilakukan melalui webinar dan workshop yang dibuka secara gratis untuk umum sebagai bentuk Pengabdian kepada Masyarakat (PkM) yang dilakukan oleh Program Studi Pendidikan Jarak Jauh Ilmu Komunikasi UPH. Selain itu, kegiatan ini juga merupakan kolaborasi antara dosen, tutor dan mahasiswa. Pada akhirnya, dengan adanya kegiatan pelatihan digitalisasi UKM ini dapat menjadi wadah bagi anggota UKM INDONESIA dan juga pelaku UMKM secara umum untuk meningkatkan kompetensi dengan melakukan praktik langsung dalam menyelesaikan masalah yang sedang dialami.

\section{METODE}

Pemberlakuan Pembatasan Kegiatan Masyarakat (PPKM) yang terjadi di seluruh wilayah di Indonesia membuat kami menyelenggarakan kegiatan ini secara daring. Kegiatan ini dikemas dalam bentuk Webinar dan Workshop pada tanggal 17 Juli 2021 pukul 19.00-21.00 WIB. Konsep dari kegiatan ini kami buat paralel dengan mengintegrasikan 2 topik kegiatan secara bersamaan. Topik yang pertama menekankan pada kemampuan pelaku UMKM untuk beriklan menggunakan fitur Facebook Ads sedangkan topik 
yang kedua berkaitan dengan membangun brand di media sosial Instagram. Kedua topik ini kami angkat dan implementasikan dalam bentuk webinar. Namun untuk topik kedua kami juga menambahkan workshop singkat terkait bagaimana membuat konten yang akan digunakan dalam membangun brand menggunakan media sosial. Kegiatan PkM diselenggarakan melalui platform Zoom Meeting. Platform ini juga sangat membantu kami untuk dapat menjangkau lebih banyak pelaku UMKM dan masyarakat umum dari seluruh Indonesia. Total peserta yang berhasil kami jangkau tercatat sejumlah 422 peserta yang terdiri dari pelaku UMKM dan juga masyarakat umum.

Metode yang kami lakukan sebelum memulai kegiatan dimulai dengan membuka pendaftaran peserta terlebih dahulu untuk mengumpulkan data dari para pelaku UMKM yang akan terlibat dalam kegiatan ini. Setelah mengetahui data-data peserta yang akan mengikuti kegiatan, kami melakukan koordinasi untuk menyesuaikan materi yang akan disampaikan dengan kebutuhan dari teman-teman pelaku UMKM yang terlibat. Kemudian, kegiatan pun dilangsungkan secara daring dan diakhiri dengan teman-teman pelaku UMKM mengisi form evaluasi yang telah kami siapkan terkait jalannya kegiatan.

Untuk menyampaikan materi webinar dan pelaksanaan workshop, kami menggunakan beberapa metode berikut ini: 1) Ceramah, yang digunakan untuk menyampaikan materi secara teoritis terkait digitalisasi yang akan dihadapi para pelaku UMKM. 2) Tanya Jawab, yang digunakan untuk memperdalam pemahaman peserta terkait materi teoritis yang sudah disampaikan sebelumnya. 3) Demonstrasi dan Praktik, yang digunakan untuk mengajak temanteman pelaku UMKM untuk sama-sama melaksanakan aktivitas yang sudah disiapkan oleh pemateri berkaitan dengan angle product, copywriting, pembuatan konten yang menarik, hingga strategi marketing melalui sosial media Instagram dan Facebook. 4) Diskusi, yang digunakan untuk memperdalam wawasan peserta terkait pelaksanaan demonstrasi atau praktik yang telah dilangsungkan

\section{HASIL DAN PEMBAHASAN}

\section{Rangkaian Kegiatan}

Rangkaian kegiatan tersebut dapat dilihat pada tabel di bawah ini:

Tabel 1. Rangkaian Pelaksanaan Kegiatan

\begin{tabular}{|c|c|}
\hline $\begin{array}{c}\text { Rangkaian } \\
\text { Kegiatan }\end{array}$ & Rincian Teknis \\
\hline Persiapan & $\begin{array}{l}\text {-Diskusi internal tim pengabdian kepada } \\
\text { masyarakat Prodi PJJ Ilmu Komunikasi } \\
\text { UPH dan Wawancara Awal dengan } \\
\text { beberapa guru yang terdampak Pandemi } \\
\text { Covid-19 sehingga diharuskan melakukan } \\
\text { kegiatan belajar daring. } \\
\text {-Persiapan Materi Webinar, Platform yang } \\
\text { digunakan baik itu Zoom maupun Google } \\
\text { Form untuk pendaftaran peserta. } \\
\text {-Koordinasi dengan peserta perihal link, } \\
\text { meeting id, dan password zoom yang akan } \\
\text { digunakan. } \\
\text {-Briefing, Koordinasi, dan Gladi Bersih } \\
\text { sebelum kegiatan berlangsung }\end{array}$ \\
\hline Pelaksanaan & $\begin{array}{l}\text {-Para peserta webinar memasuki ruang } \\
\text { meeting virtual sesuai dengan kegiatan } \\
\text { yang didaftarnya. } \\
\text { - Host/MC membuka acara dengan } \\
\text { menyampaikan informasi dan aturan main } \\
\text { selama kegiatan berlangsung. } \\
\text {-Metode ceramah digunakan oleh para } \\
\text { pemateri untuk memberikan penjelasan } \\
\text { mengenai branding dan Facebook Ads } \\
\text {-Metode tanya jawab digunakan oleh } \\
\text { pemateri setelah selesai memberrikan } \\
\text { pemaparan materi. } \\
\text { - Untuk topik mengenai branding } \\
\text { pemateri juga memberikan peragaan dan } \\
\text { juga praktek secara langsung dalam } \\
\text { membuat konten yang dapat digunakan } \\
\text { dalam media sosial seperti Instagram. Hal } \\
\text { ini dilakukan agar peserta dapat lebih } \\
\text { memahami bentuk pengaplikasian materi } \\
\text { yang disampaikan oleh pemateri } \\
\text { sebelumnya. }\end{array}$ \\
\hline Evaluasi & $\begin{array}{l}\text {-Peserta memberikan tanggapan lewat } \\
\text { survey yang dibagikan diakhir sesi untuk } \\
\text { mengukur sejauh mana tingkat } \\
\text { keberhasilan kegiatan PkM. } \\
\text {-Evaluasi kegiatan secara internal oleh } \\
\text { panitia penyelenggarra yang terdiri dari } \\
\text { dosen, tutor dan mahasiswa Prodi PJJ } \\
\text { Ilmu Komunikasi UPH.. }\end{array}$ \\
\hline
\end{tabular}

\section{Materi}

Ekonomi, Sosial, dan Budaya 1204 
Marketing atau pemasaran merupakan salah satu kegiatan yang memiliki peranan untuk memperkenalkan atau mempromosikan suatu produk atau jasa. Dalam melakukan pemasaran terutama melalui media digital pelaku pemasaran terlebih dahulu harus melakukan perencanaan strategi yang sesuai dengan target yang ingin dicapai. Bentuk strategi yang secara umum dapat dilakukan adalah dengan melakukan marketing mix (bauran pemasaran yaitu 4P yang meliputi Product, Packaging, Proposition dan Promotion. Dengan melalukan strategi ini maka pelaku UMKM dapat menentukan dengan cepat dan efektif target pasar agar mudah diterima oleh masyarakat.

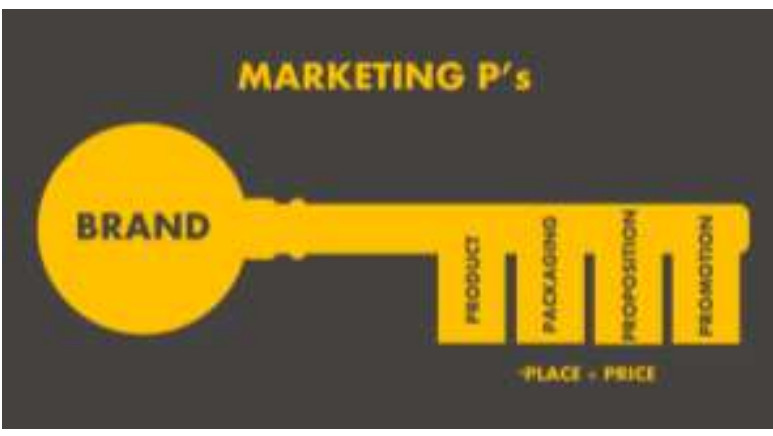

Gambar 1Marketing P's

Setelah menentukan strategi pemasaran yang sesuai maka dapat dilanjutkan kepada tahapan Marketing Campaign (Kampanye Pemasaran) guna membangun citra di masyarakat. Kegiatan ini sangat penting bagi pelaku UMKM karena dapat memberikan edukasi mengenai cara memperkenalkan produk yang tepat sesuai dengan target dan juga pelaku UMKM dapat melihat peluang serta permasalahan yang ada dalam masyarakat. Pelaku UMKM menjadi memahami Bagaimana merencanakan sebuah kampanye pemasaran yang kreatif.

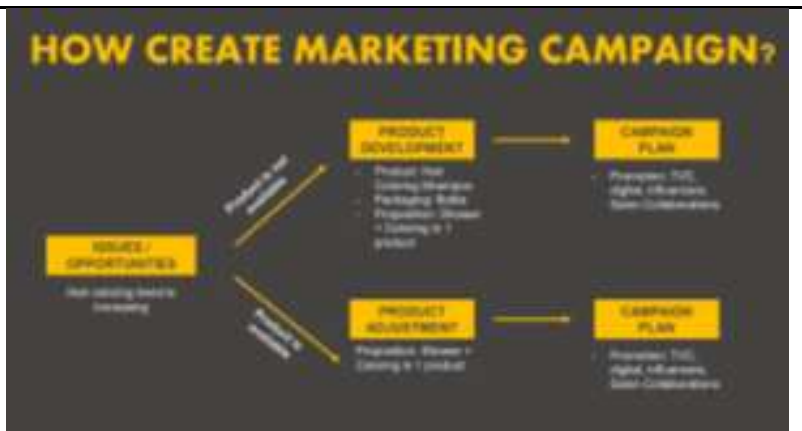

Gambar 2 How to Create Marketing Campaign

Media sosial merupakan salah satu media yang saat ini banyak digunakan oleh pelaku pemasaran. Hal tersebut karena dengan menggunakan media sosial maka pemasaran dapat dilakukan dengan cepat dan efisien. Salah satu media sosial yang ramai digunakan saat ini adalah Instagram. Berdasarkan data yang dilansir dari We Are Social, media sosial Instagram merupakan media sosial yang memiliki pengguna mencapai $86.6 \%$ di Indonesia. Oleh karena itu pengetahuan mengenai pemasaran dengan media sosial menjadi hal penting bagi pelaku UMKM saat ini agar para dapat mempromosikan suatu produk atau jasa dengan tepat sasaran.

\section{KESIMPULAN}

Dengan diadakannya webinar serta workshop, kami melihat pelaku UMKM dan masyarakat umum berhasil mendapatkan ilmu dan informasi baru yang berguna bagi mereka untuk dalam usaha peningkatan kualitas dari brand UMKM. Para pelaku UMKM mulai mengenal dengan digitalisasi. Peserta juga terlihat sangat antusias untuk bertanya secara langsung kepada pemater sebagai bentuk dari usaha mereka dalam memajukan kreativitas mereka di bidang branding pemasaran.

Namun meskipun peserta sangat antusias dan berhasil mendapatkan ilmu dan informasi baru, kami juga melihat bahwa para pelaku UMKM terutama, masih memiliki pemahaman yang kurang dalam menerapkan pemasaran secara digital. Hal ini terlihat dengan masih banyak peserta yang merupakan pelaku UMKM hanya memanfaatkan perkembangan teknologi seadanya saja dalam melakukan pemasaran. Tidak sedikit juga pelaku 
UMKM yang menggunakan jasa pihak ketiga dalam usahanya memasarkan produk UMKMnya melalui media digital. Tentunya hal ini apabila tidak dikelola dengan baik akan memberatkan pelaku UMKM dari sisi finansial. Besarnya biaya yang digunakan terkadang tidak berbanding lurus dengan keuntungan yang ingin dicapai.

Adapun saran untuk keberlanjutan kegiatan ini ialah setelah kami melakukan survey dari para peserta, adalah sebagian peserta merupakan peserta yang berasal dari luar Jakarta, sehingga kendala perbedaan waktu dirasakan oleh peserta. Untuk itu keberlanjutan PKM ini harus memperhatikan waktu yang tepat. Selain itu peserta menginginkan agar acara ini terus dilakukan secara berkala dengan mengundang narasumber milenials atau dari pemerintahan seperti dari Kementerian Pariwisata dan Ekonomi Kreatif, Kementerian Perdangan dan berbagai Instansi maupun pakar dibidang yang dapat mendukung perkembangan Digitalisasi UMKM.

\section{UCAPAN TERIMAKASIH}

Penulis mengucapkan terima kasih kepada Program Studi Pendidikan Jarak Jauh Fakultas Ilmu Sosial dan Ilmu Politik Universitas Pelita Harapan yang telah memberikan dukungan hingga kegiatan ini dapat berlangsung dengan baik. Selain itu juga tidak lupa kami ucapkan terima kasih kepada para mahasiswa yang juga turut terlibat dari persiapan hingga pelaksanaan kegiatan ini.

\section{REFERENSI}

Andriyanto, R. (2021, Januari 20). https://glints.com/id/lowongan/strategipemasaran- produk-online/\#.YMoFL-AzbIU. Retrieved from glints.com.

Badan Pusat Statistik. (2021, February). Ekonomi Indonesia 2020 Turun Sebesar 2,07 Persen. Badan Pusat Statistik. https://www.bps.go.id/pressrelease/2021/02/05/ 1811/ekonomi-indonesia-2020-turun-sebesar-207-persen--c-to-c-.html
Betty Eliya, I. Y. (2020). Tantangan, Kendala, dan Kesiapan Pemasaran Online UMKM di Desa Nglebak, Kec Tawangmangu Kabupaten Karanganyar.

Fajariana, D. U. (2018). Strategi Pemasaran Melalui Media Sosial Instagram (Studi Deskriptif pada Akun @Subur_Batik). Jurnal Sekretari dan Manajemen, 271-278.

Hendayana, Y. (2021, Januari 15). UKM IndonesiaLPEM FEB UI Prakarsai Katalog Daring "100 UKMJUWARA" Sebagai Media Promosi UKM di Indonesia. Retrieved from dikti.kemdikbud.go.id.

Kotler, P., Kartajaya, H., \& Setiawan, I. (2021). Marketing 5.0 Technology for Humanity. New Jersey: John Wiley \& Sons, Inc.

Luqman, M. U. (2019). Strategi Pemasaran Melalui Media Sosial Instagram. Jurnal Program Studi Manajemen, 12-18.

Moriansyah, L. (2015). Pemasaran Melalui Media Sosial: Antecedents and Consequences. Jurnal Penelitian Komunikasi dan Opini Publik, 187-196.

Niode, I. Y. (2009). SEKTOR UMKM DI INDONESIA: Profil, Masalah, Dan Strategi Pemberdayaan, 5.

Suci, Y. R. (2017). PERKEMBANGAN UMKM (USAHA MIKRO KECIL DAN MENENGAH) DI INDONESIA, 54. 